\title{
Diet, activity and body-weight. A study of variations in a woman
}

\author{
BY NAN TAGGART \\ Obstetric Medicine Research Unit (Medical Research Council), \\ Maternity Hospital, Aberdeen \\ (Received 25 September 196ז-Revised 7 December $196 \mathrm{I}$ )
}

Metabolic and clinical investigations may involve the measurement of comparatively small changes in body-weight between the beginning and end of a period. Even with accurate scales and a carefully standardized procedure, the results may be distorted or obscured by short-term fluctuations of weight, which are difficult to control because their nature is not fully understood. These rapid fluctuations were referred to several times at a recent symposium of The Nutrition Society on Calorie Balance in Man. Durnin (I96I) mentioned changes in weight from day to day of up to I $\mathrm{kg}$ in a group of forty-four men living under controlled conditions, and Edholm (I96I) reported that in a group of twelve young soldiers weighed daily for a period of 7 weeks, a weight change of more than $0.5 \mathrm{~kg}$ from one day to the next was found on over a hundred occasions and weight changes of $\mathrm{I} \mathrm{kg}$ or more were observed on thirty occasions. Elkinton \& Danowski (I955) found a maximum weight change of about I kg from one day to the next, in one man whose basal body-weight was determined on 53 of 56 consecutive days; the standard deviation of body-weight was $\pm 0.86 \mathrm{lb}$ or $\pm 0.5 \mathrm{I} \%$ of the body-weight. Graphs of the daily basal weight of fourteen women for 35 days, published by Thomas (1953), show similar weight fluctuations. The literature otherwise contains very little information about daily weight changes.

The original object of the study reported here was to investigate possible changes in weight and food intake related to the menstrual cycle in one subject. Such changes were not found, but the figures collected illustrate the extent of daily fluctuations in weight and help to explain them in terms of food intake, water balance and activity.

\section{EXPERIMENTAL}

Procedure. Daily measurements of food and water intake, body-weight and urine output were made on one subject during two periods. During the first period (A) of 80 days ( 8 October to 26 December 1958), ordinary food habits and activities were maintained and a record of activity was kept for part of the time. During a second period (B) of 35 days (9 April to I3 May 1959) food intake was kept constant and activity was kept as constant as was consistent with ordinary duties at work and at home.

Subject. The subject, a healthy female aged 3 I years, was doing full-time laboratory 
work. Her weight has been about $64 \mathrm{~kg}$ since adolescence, with little obvious change, and her height is $168 \mathrm{~cm}$. Menstruation was regular, with bleeding for $3^{-4}$ days in a 25 day cycle. Daily activity was light; during working hours ( 9 a.m. -5.30 p.m.) and recreation the time was about equally divided between sitting activities and activities which involved moving around, mostly indoors. Hours of work were regular, with a half-day on Saturday and no work on Sunday.

Environmental temperature. During period (A), the mean value of the maximum day temperature outdoors was $9.4^{\circ}$ (range $1.5^{\circ}-18^{\circ}$ ) and the mean value of the minimum night temperature outdoors $2 \cdot 6^{\circ}$ (range $-5 \cdot 5^{\circ}-9^{\circ}$ ). The corresponding figures for period (B) were, day $12.3^{\circ}\left(8 \cdot 5^{\circ}-16.5^{\circ}\right)$ and night $4.2^{\circ}\left(-I^{\circ}-9.5^{\circ}\right)$. Work was done in a heated building where the indoor temperature was usually maintained at about $21^{\circ}$.

Body-weight. Body-weight was measured on weekdays (Monday to Saturday) in the laboratory, between 9 a.m. and $9.3 \circ \mathrm{a} . \mathrm{m}$., on a lever balance weighing to 20 stones by I oz. For convenience, indoor clothes were weighed on a counterpoise domestic food balance each day before dressing and their weight was deducted from the weight of the clothed body subsequently measured in the laboratory. To ensure standard conditions for the measurement of body-weight $24 \mathrm{~h}$ urine collections were completed at 8 a.m.; no urine was voided between 8 a.m. and io a.m. and no food or water was taken between midnight and to a.m. This was the only alteration in usual eating habits during period (A). Normally a light breakfast would have been eaten before Io a.m.

Since a special visit to the laboratory at $9 \mathrm{a} . \mathrm{m}$. on Sundays would have been inconvenient as well as a break with customary routine, body-weight was not measured on Sundays. It later became evident that this was an unfortunate omission.

Food intake. All food and drink was weighed on dietetic scales weighing to $500 \mathrm{~g}$ by $2 \mathrm{~g}$; no vitamin supplements or medicines were taken. Christmas dinner was not eaten until 28 December, after the end of period (A). The pattern of eating during period (A) was dictated by choice and by custom alone.

The protein, fat and carbohydrate content of each day's diet was calculated mainly from the tables of McCance \& Widdowson (1946), the Medical Research Council: Accessory Food Factors Committee's (1945) Nutritive Value of Wartime Foods, and unpublished tables provided by the Ministry of Agriculture, Fisheries and Food. Calorie values were calculated from the protein, fat and carbohydrate (expressed as monosaccharide) content of each diet by means of the factors 4,9 and $3.75 \mathrm{kcal} / \mathrm{g}$, respectively. No calculation was made until after the end of period (A).

Throughout period (B) the calculated intakes of protein, fat, carbohydrate and calories were each day equal to the mean values during the second menstrual cycle of period (A), from day 33 to day 57 inclusive; body-weight had shown no progressive change during that time. The intakes were $86 \mathrm{~g}$ protein, $126 \mathrm{~g}$ fat and $269 \mathrm{~g}$ carbohydrate (expressed as monosaccharide), providing $2480 \mathrm{kcal}$ daily. The individual foods eaten, and their weights, were the same every day and foods likely to have a fairly constant composition were chosen. No salt was used in cooking and the same weight of salt was used each day at table. Water was taken as desired, since informa- 
tion was sought on the extent to which total water intake would vary when uninfluenced by changes in food intake, and when activity was less varied than usual.

Water intake and output. Urine was collected daily from 8 a.m. to 8 a.m., throughout both periods of study. Water in faeces was not measured.

Water, tea and black coffee were weighed; these are later referred to as 'non-food water'. The amount of preformed water in food, including solid foods and fluid foods such as milk, was calculated from the tables of McCance \& Widdowson (1946), and that of water of oxidation was calculated by means of the factors: protein $0^{\circ} 4 \mathrm{r}$, fat I.07, carbohydrate $0.6 \mathrm{~g}$ water/g (Passmore, Meiklejohn, Dewar \& Thow, 1955). Since the amounts of protein, fat and carbohydrate katabolized were unknown, the factors were applied to the nutrient intakes; this procedure is not likely to be seriously misleading under conditions of approximate energy equilibrium. The term 'total water intake' as used in this paper refers to the sum of the non-food water, the preformed water in food, and the water of oxidation.

Activity. During the first 30 days of period (A) activities were timed and subsequently classified as: (I) in bed; (2) sitting (e.g. in public transport, listening to radio, at cinema or concert); (3) sitting activity (reading, writing, knitting, sewing, talking, driving car); (4) light activity (at work in laboratory, standing or walking indoors, cooking, housework, washing and dressing); (5) walking outdoors; and (6) more strenuous activity (swimming, gardening, cycling).

An attempt was made during period (B) to regulate activity so that energy expenditure would be relatively constant. From the record of activity kept during period (A) it appeared that the times which varied most from day to day, or with the day of the week, were the times spent in bed, in walking outside, and in more strenuous activities. Throughout period (B), therefore, $420 \mathrm{~min}$ (the daily mean for period (A)) were spent in bed each night and $50 \mathrm{~min}$ in walking outdoors each day. The rest of the time was spent indoors or travelling by car.

Other measurements. Pulse rate and oral temperature were taken daily just before rising. The daily excretion of pregnanediol and of oestriol in urine was estimated during the second menstrual cycle of period (A) and throughout period (B). Pregnanediol was estimated by the method of Klopper, Michie \& Brown (1955) and oestriol by the method of Brown (1955) as modified by Brown, Bulbrook \& Greenwood $\left(1957^{-8)}\right.$.

\section{RESULTS}

Table I and Fig. I summarize the measurements of body-weight, calorie intake, total water intake and urine volume.

Mean body-weight was about I kg greater in period (B) than in period (A), but in each period the first and last weights were about the same (the differences were smaller than the daily variation) indicating that during them approximate energy balance was maintained. In each period there were quite large variations of weight, from $6 \mathrm{I} \cdot 5$ to $63.9 \mathrm{~kg}$ in period (A) and from 63.5 to $64.5 \mathrm{~kg}$ in period (B). Changes up to $0.8 \mathrm{~kg}$ were recorded between two consecutive weighings in period (A) and up to $0.4 \mathrm{~kg}$ in period (B). Weights were not recorded on Sundays, so that at the weekends 


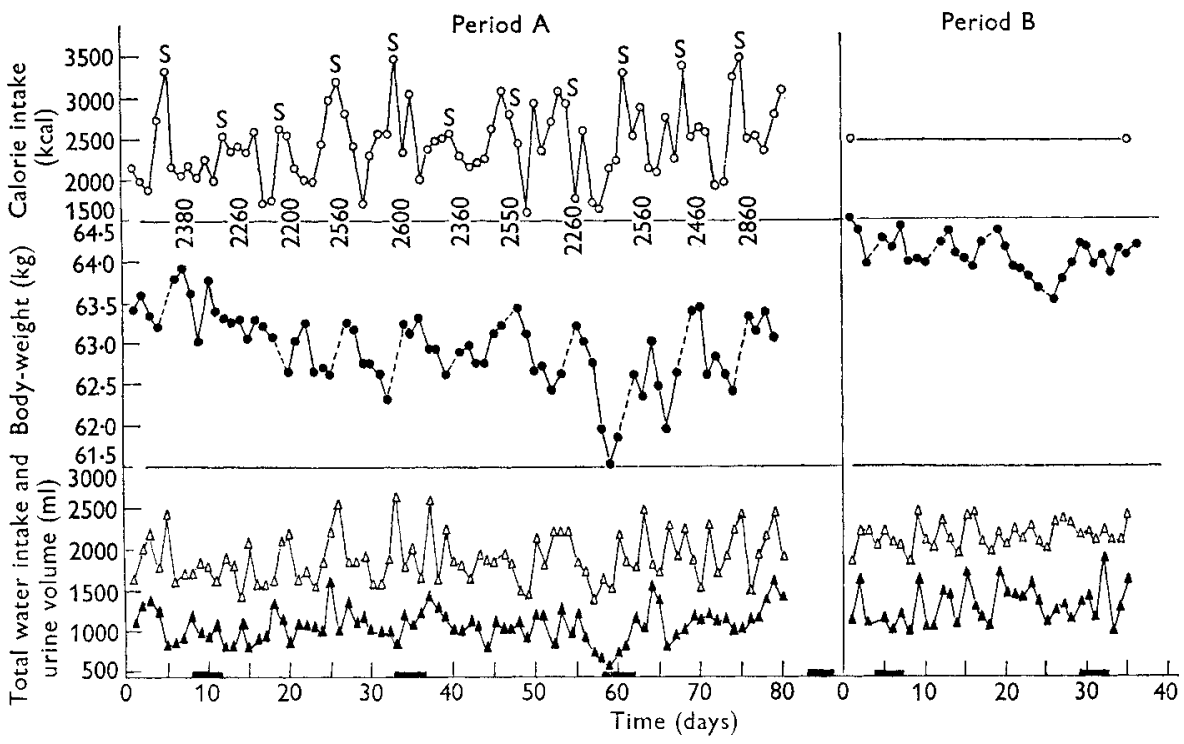

Fig. I. Daily measurements for one woman of calorie intake $(0-0)$, body-weight ( - $\bullet$ for weekdays, - - - for weekends), total water intake $(\Delta-\Delta)$ and urine volume $(\Delta-\Delta)$ in periods (A) and (B). On the calorie intake curve Sundays are marked $S$, and the figures below the curve are mean calorie intakes (kcal/day) for each week, from day 4 to day 80 inclusive, of period (A). The occurrence of menstruation is shown on the abscissa (- - ).

Table I. Body-weight, daily change in body-weight, intake of calories and water, and urine volume of a woman in periods $(A)$ and $(B)^{*}$

$$
\begin{array}{cc}
\text { Period (A) Period (B) } & \text { Pody-weight }(\mathrm{kg})
\end{array}
$$

Initial

Final

Meant

Ranget

Rangef

Mean and SD

Range

Mean and SD

Range

Mean and SD Range

$\begin{array}{cc}63 \cdot 4 & 64 \cdot 5 \\ 63 \cdot I & 64 \cdot 2 \\ 62 \cdot 9 & 64 \cdot I \\ 6 I \cdot 5 I-63 \cdot 9 I & 63 \cdot 50-64 \cdot 52\end{array}$

Change in body-weight from one day to the next $(\mathrm{kg})$

$-0.8 \mathrm{I}-+0.77 \quad-0.43^{-+0.3 I}$

Calorie intake (kcal/day)

$2440 \pm 460$
$1570-3490$

Total water intake ( $\mathrm{ml} / \mathrm{day})$

$\begin{array}{ll}\text { r } 870 \pm 304 & 2145 \pm x 66 \\ \text { I 350-2630 } & \text { I } 800-2465\end{array}$

Urine volume ( $\mathrm{ml} /$ day)

$\begin{array}{rr}\text { IO5O } \pm 213 & \text { I } 290 \pm 246 \\ 550-1620 & 950-1875\end{array}$

SD, standard deviation.

* See p. 223.

$\uparrow$ Sundays excluded (see p. 224).

$\ddagger$ Saturdays and Sundays excluded (see p. 224). 
even larger day-to-day variations may have occurred during period (A), though probably not in period (B).

Calorie intakes in period (A) ranged from 1570 to $3490 \mathrm{kcal} /$ day and, as shown in Fig. I, there were peaks at intervals of about I week. Table 2 shows the mean calorie intakes on each day of the week, and it is clear that intakes were usually much greater at weekends than in mid-week, an average of about $850 \mathrm{kcal}$ more being taken on Sundays than on Wednesdays and Thursdays. Until the values for period (A) had been calculated, the subject did not realize that she ate more at weekends and at no time was she conscious of undue hunger or repletion. During period (B) also, when food intake was held constant, there was no alimentary discomfort.

Table 2. Period $(A)$. Mean values for each day of the week, and for the whole period, for calorie intake, total water intake, urine volume, total water intake minus urine volume $\left(W_{r}\right)$ and change in body-zweight of a woman

$\begin{array}{lccccc} & \begin{array}{c}\text { Calorie } \\ \text { intake } \\ (\mathrm{kcal})\end{array} & \begin{array}{c}\text { Total } \\ \text { water } \\ \text { intake } \\ (\mathrm{ml})\end{array} & \begin{array}{c}\text { Urine } \\ \text { volume } \\ (\mathrm{ml})\end{array} & \begin{array}{c}W_{r} \\ (\mathrm{~m})\end{array} & \begin{array}{c}\text { Change in } \\ \text { body-weight } \\ \text { Day of the week }\end{array} \\ \text { Monday } & 2380 & 1750 & 1060 & 690 & -50 \\ \text { Tuesday } & 2390 & 1730 & 1020 & 710 & -130 \\ \text { Wednesday } & 2190 & 1850 & 1120 & 730 & -210 \\ \text { Thursday } & 2180 & 1830 & 1095 & 735 & -70 \\ \text { Friday } & 2380 & 1840 & 1010 & 830 & -20 \\ \text { Saturday } & 2580 & 1970 & 1110 & 860 & +460 \\ \text { Sunday } & 3050 & 2170 & 930 & 1240) & - \\ \text { Mean for 80 days } & 2440 & 1875 & 1050 & 825 & -\end{array}$

During period (A) the total water intake varied from $135^{\circ}$ to $2630 \mathrm{ml} /$ day and during period (B) from I 800 to $2465 \mathrm{ml} /$ day. The higher mean intake in period (B) was probably due mainly to the inclusion of a fixed volume of lime-juice cordial in the constant diet; during period (A), if a similar drink was taken, it usually replaced some other beverage. As might be expected, the urine volume was greater in period (B) than in period $(A)$.

\section{Food intake, water intake and urine volume}

As Table 3 shows, there was during period (A) a fairly close association $(r=0.6 \mathrm{I})$ between calorie intake and total water intake. It was due not to drinking more beverages when food intake increased, but to extra water obtained from food, as preformed water and water of oxidation. There was no correlation $(r=-0 \cdot 10$, not significant) between calorie intake and intake of water not derived from food.

During period (A) there was little correlation $\left(r=0 \cdot I_{4}\right.$, not significant) between total water intake and urine volume, but during period (B) the correlation coefficient rose to $0.59(P<0.005)$. Since the water derived from food was constant during period (B) the association is, of course, between non-food water and urine volume. In interpreting these correlations it should be remembered that activity was less variable during period (B) than during period (A), and thus losses of water through the skin and lungs may also have been less variable. 


\section{Associations between body-weight and food intake}

During period (A) the general trend of body-weight followed that of calorie intake. The mean daily calorie intakes in successive weeks are shown below the calorie intake curve in Fig. I and it can be seen that body-weight tended to fall when calorie intakes became less and to rise when they increased. During period $(B)$, when the calorie intake was constant, the fluctuations of body-weight did not show any general trend upwards or downwards.

Table 3. Correlation coefficients for periods $(A)$ and $(B)$

\begin{tabular}{|c|c|c|c|}
\hline & Period & $r$ & $P$ \\
\hline Calorie intake and total water intake & (A) & $0.6 I$ & 0.001 \\
\hline Calorie intake and non-food water & (A) & -0.10 & NS \\
\hline Total water intake and urine volume & (A) & 0.14 & NS \\
\hline & (B) & 0.59 & 0.005 \\
\hline $\begin{array}{l}\text { Weight change* and calorie intake on same day } \\
\text { Weight change* and calorie intake on previous day }\end{array}$ & (A) & $\begin{array}{r}0.35 \\
-0.05\end{array}$ & $\begin{array}{l}\text { O०OI } \\
\text { NS }\end{array}$ \\
\hline Weight change* and $W_{r}$ on same day & (A) & 0.68 & 0.001 \\
\hline$E$ and calorie intake on same day & (A) & 0.17 & NS \\
\hline$E$ and calorie intake on next day & (A) & 0.55 & 0.005 \\
\hline$E$ and $W_{r}$ on same day & (A) & -0.07 & NS \\
\hline$E$ and $W_{r}$ on next day & (A) & 0.40 & 0.05 \\
\hline
\end{tabular}

NS, not significant; $W_{r}$, total water intake-urine volume (see p. 229); $E$ is a measure of daily energy expenditure; for method of calculation see p. 230.

* Measured on weekdays only.

There was also some association, during period (A), between daily changes in weight and daily calorie intakes. For weekdays only the correlation coefficient between weight change and calorie intake on the same day was 0.35 (Table 3 ) but there was no correlation between weight change on one day and calorie intake on the previous day $(r=-0.05)$. On nine of the eleven weekends in period (A) the mean calorie intake on Saturday and Sunday was above the daily mean for the whole period, and on these nine weekends there was a gain in body-weight. On the two weekends when the mean calorie intake was less than the mean for period $(A)$, there was a loss of weight. As Table 2 shows, there was a mean gain of weight of $460 \mathrm{~g}$ at weekends and a mean loss on all other days of the week, with the greatest loss in mid-week when the mean calorie intake was lowest.

During period (B), when the diet was the same each day and when activity was regulated, body-weight varied less than during period (A) but was by no means constant.

\section{Associations between body-weight and water balance}

The water balance of the body may be expressed by the equation:

$$
\underset{\text { intake }}{\text { Total water }}=\underset{\text { retention }}{\text { water }}+\begin{aligned}
& \text { insensible* } \\
& \text { water loss }
\end{aligned}+\begin{gathered}
\text { water output } \\
\text { in faeces }
\end{gathered}+\begin{gathered}
\text { water output } \\
\text { in urine }
\end{gathered} .
$$

* Strictly, 'respiratory and skin water losses'. Since no noticeable sweating took place, this term has been simplified to 'insensible water loss'. 
It follows that:

$$
\begin{array}{r}
\begin{array}{r}
\text { Total water } \\
\text { intake }
\end{array}-\underset{\text { volume }}{\text { urine }}=\underset{\text { retention }}{\text { water }}+{ }_{\text {water loss }}^{\text {insensible }}+\stackrel{\text { water output }}{\text { in faeces }} \\
\\
-\left(\begin{array}{c}
\text { urine } \\
\text { volume }
\end{array}-\begin{array}{c}
\text { water output } \\
\text { in urine }
\end{array}\right) .
\end{array}
$$

The interest is in variations in these quantities, rather than in absolute values.

Insensible water loss may vary with atmospheric temperature and relative humidity (Osborne, I910; Wiley \& Newburgh, I931 ; Brebner, Kerslake \& Waddell, I956), and with energy expenditure (Newburgh, I950; Heller, I932). Faecal water loss presumably depends partly on the quantity of food eaten and on the amount of fibre it contains. The value of (urine volume - water output in urine) is determined by the total

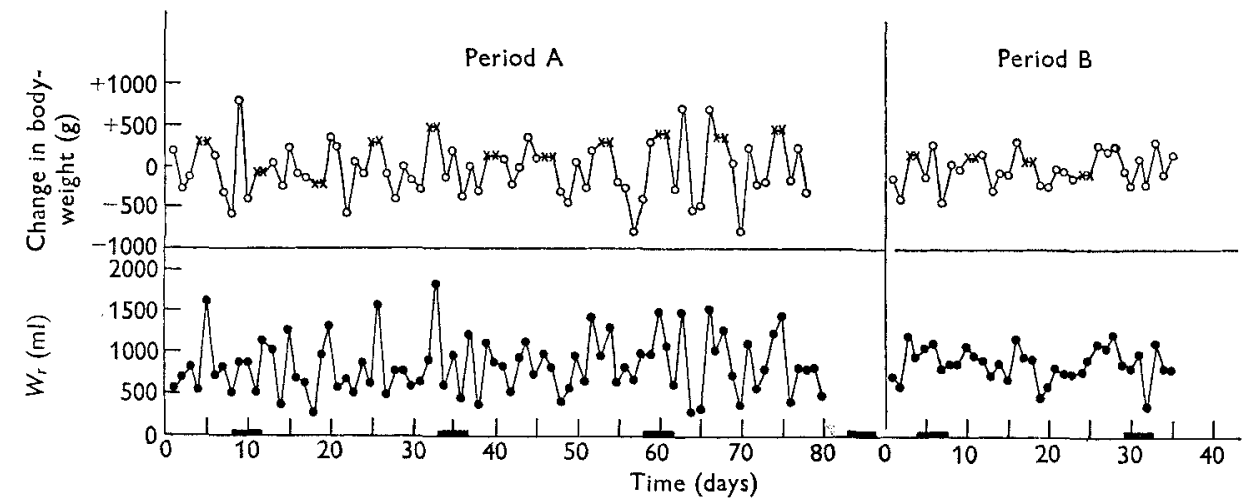

Fig. 2. Daily changes in body-weight of one woman from one day to the next ( -0 for weekdays and $x-x$ for the 2 days in each weekend) and in (total water intake - urine volume $\left.\left(W_{r}\right)\right)(-\bullet)$ in periods $(A)$ and $(B)$. Changes in weight on Saturdays and Sundays $(x-x)$ are shown as half the change from Saturday to Monday. The occurrence of menstruation is shown on the abscissa (- - ).

urine solids which will depend on the total metabolism and on the amount of $\mathrm{NaCl}$ and other salts in the food eaten. Hence, if food intake, energy expenditure, ambient temperature and relative humidity were constant, we should expect variations in (total water intake - urine volume) (henceforth denoted by $W_{r}$ ) to reflect variations in water retention by the body. Apart from changes in relative humidity throughout the day and in atmospheric temperature during the 50 min spent outdoors each day, an approximation to these conditions was made during period (B). During period (A), when food intake and energy expenditure as well as ambient temperature and relative humidity varied from day to day, variations in $W_{r}$ would be a less sensitive index of changes in water retention by the body.

Fig. 2 shows the daily changes in body-weight and daily values of $W_{r}$. There is obviously a crude resemblance between the curves. Both weight change and the values of $W_{r}$ were less variable in period (B) than in period (A). For weekdays the correlation coefficient between change in body-weight and $W_{r}$ was 0.68 during period (A) and 0.80 during period (B). Both correlations are highly significant. 


\section{Influence of activity on calorie intake and water balance}

Table 4 gives the mean times spent in five groups of activities on each day of the week during the first 30 days of period (A). The times were similar from Monday to Friday. On Saturdays about 170 min less were spent in sitting activities, 15 min more in sitting, 80 min more in light activities and 70 min more in walking and more strenuous activity, usually swimming. On Sundays the subject spent $200 \mathrm{~min}$ longer in bed, 150 min less in both sitting activity and light activity, and 100 min more in walking and more strenuous activity than on weekdays.

Table 4. Mean times (min) spent in five groups of activities* by a woman on each day of the week for the first 30 days of period $(A)$

\begin{tabular}{|c|c|c|c|c|c|}
\hline \multirow[b]{2}{*}{ Day of the week } & \multicolumn{5}{|c|}{ Time spent } \\
\hline & In bed & Sitting & $\begin{array}{l}\text { Sitting } \\
\text { activity }\end{array}$ & $\begin{array}{l}\text { Light } \\
\text { activity }\end{array}$ & $\begin{array}{l}\text { Walking } \\
\text { and more } \\
\text { strenuous } \\
\text { activity }\end{array}$ \\
\hline Monday & 385 & 105 & 545 & 395 & Io \\
\hline 'Tuesday & 380 & 70 & 580 & 375 & 35 \\
\hline Wednesday & 400 & 85 & 425 & 500 & 30 \\
\hline 'Thursday & 415 & 75 & 540 & 370 & 40 \\
\hline Friday & 385 & 35 & 520 & 490 & Io \\
\hline Saturday & 400 & 90 & $35^{\circ}$ & 505 & 95 \\
\hline Sunday & 600 & 80 & $3^{6} 5$ & 270 & I 25 \\
\hline Mean for weekdays & 395 & 75 & 520 & 425 & 25 \\
\hline Mean for 30 days & 420 & - & - & - & 50 \\
\hline
\end{tabular}

No information was available about the rate of energy expenditure of the subject on various tasks, but the values chosen as representative for a younger, lighter woman by the FAO: Second Committee on Calorie Requirements (1957) may be used, together with the record of the subject's activity, to give estimates of daily energy expenditure which should be fairly reliable for the purposes of internal comparison. On the basis of these values it seems likely that about the same amount of energy was spent on Sundays as on weekdays, but that energy expenditure was about $200 \mathrm{kcal}$ greater on Saturdays. Yet, on the average, the food taken on Sundays provided about $75^{\circ} \mathrm{kcal}$ more than on weekdays (Mondays to Fridays) and $470 \mathrm{kcal}$ more than on Saturdays.

The daily energy expenditure $(E)$ of the subject, estimated as described, was compared with calorie intake and with $W_{r}$. Correlation coefficients obtained were: between $E$ and calorie intake on the same day ${ }^{\circ}$ I $_{7}$; between $E$ and calorie intake on the next day 0.55 ; between $E$ and $W_{r}$ on the same day -0.07 ; between $E$ and $W_{r}$ on the next day 0.40 (Table 3 ). It appears, therefore, that a high energy expenditure on one day tended to be followed by a high calorie intake and water retention on the following day. Correlation coefficients between $E$ and weight change have not been calculated since activity was recorded during I month only and body-weight was not measured on Sundays. 
As already explained, the intention during period (B) was to reduce as far as possible day-to-day variations in energy expenditure. In practice, although day-time pursuits were similar each day and the same time was spent in bed each night, subjective feelings of a desire for muscular activity or of lethargy varied and may have affected energy expenditure.

\section{Influence of menstruation}

Fig. I shows when menstruation occurred. It was not associated with any discernible effect on body-weight, food intake, total water intake or water balance. Changes of appetite and thirst were never obtrusive. Activity was not affected by menstruation,
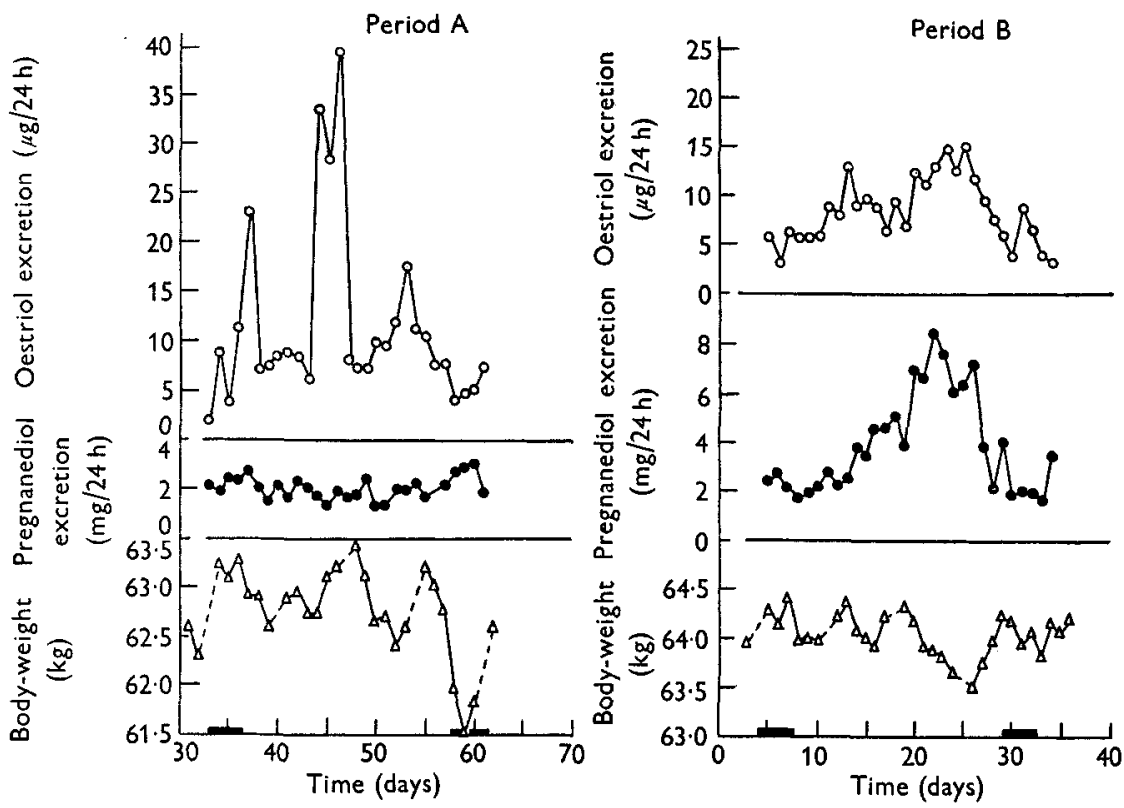

Fig. 3. Urinary excretion by one woman of oestriol ( $0-0)$ and of pregnanediol (- $-\bullet)$, and body-weight $(\Delta-\Delta)$, during the second menstrual cycle of period $A$ and during period $B$. The occurrence of menstruation is shown on the abscissa (__ _

but subjective feelings of energy were somewhat greater about mid-cycle. The morning pulse rate, which varied from 46 to $66 / \mathrm{min}$, was not related to the phase of the menstrual cycle. In all four cycles the basal temperature rose at about mid-cycle.

Outputs of pregnanediol and oestriol in the urine were measured during the second menstrual cycle of period (A) and the whole of period (B) since it was thought that oestrogenic activity at least might influence water retention and hence body-weight. The findings are shown in Fig. 3. The menstrual cycle of period (B) appears to have been normal, but during the second cycle of period (A) pregnanediol output failed to rise; this is discussed below. 


\section{DISCUSSION}

\section{Short-term fluctuations in body-weight}

Fluctuations of body-weight from day to day in period (A) were significantly related to daily changes in calorie intake, but the correlation was low $(r=0.35)$. Moreover, the observed changes in body-weight from one day to the next were too great to be accounted for by the changes in calorie intake that occurred. That such transient changes in energy balance are relatively unimportant as causes of day-to-day variations in weight was confirmed by the fact that during period (B), when diet was held constant and activity was regulated, daily changes of body-weight were reduced but by no means eliminated.

It is clear that the main cause of day-to-day changes in body-weight, at least under conditions of approximate energy equilibrium, is fluctuation in water balance. During period (A) the correlation coefficient relating weight change to apparent water retention $\left(W_{r}\right)$ on the same day was 0.68 , and during period $(\mathrm{B})$ it rose to 0.80 .

Part of the fluctuation in weight was no doubt due to true differences in body hydration. The volume of blood, and probably of the extracellular water generally, alters in response to many influences (Manery, 1954). Since water intake is intermittent, and water is lost continuously but at varying rates in urine and through the skin and lungs, the volume of total body water is always in a state of flux.

In addition to fluctuations in the volume of true body water, there are fluctuations of water in the lumen of the gut which are equally difficult to control. Differences in weight of food residues are presumably related to the recent food intake, and the amount of water associated with these residues is probably much greater a few hours after ingestion of food than when most of the gut contents are in the lower bowel. Differences of body-weight attributable to changes in intestinal contents were reduced during period (B), when the same foods were eaten each day, though not always at the same times each day. During period (A) the association between calorie intake and weight change may have been due partly to the change in weight of food residues and accompanying water in the intestinal tract with change in food intake. Cumming \& Morrison (I960) have shown the importance of making due allowance for the water in the gut contents of rats. It is probably unnecessary to assume that much of the correlation was due to rapid transfer of nutrients into and away from the 'tissue solids'.

It may be that the conditions under which body-weight was measured could have been more accurately standardized in period (B) if the same foods had been eaten at the same time each day and fixed quantities of water had been drunk at fixed times; but no food or water had been taken since the evening before weighing at 9 a.m., and it seems unlikely that this further refinement would have had much effect.

\section{Gradual changes in body-weight: weight regulation}

The subject's body-weight has not varied by more than about $4 \mathrm{~kg}$ since adolescence and during each of the periods investigated the picture as a whole was one of equilibrium. Nevertheless, during period (A) slow changes of weight were superimposed on the 
rapid daily fluctuations discussed above. From week to week the general trend of body-weight followed that of the calorie intake.

This finding is not surprising. What is more interesting is the fact that the daily calorie intakes varied by more than $100 \%$ and that even the considerable increase in food intake at most weekends had not been recognized by the subject before the daily calorie values of the diet had been calculated. The variations of calorie intake were not significantly related to estimated energy expenditure on the same day; though a significant and larger correlation $(r=0.55)$ was found between estimated energy expenditure on one day and calorie intake on the next. It appears that quite large deficits or excesses of calorie intake, compared with current requirements, can exist for short periods without causing or being caused by obvious changes in appetite. During these short periods of imbalance appetite may perhaps be 'buffered' by tissue reserves. Over longer periods some mechanism not yet understood regulates energy balance so that body-weight is maintained at a roughly constant level despite relatively large swings from day to day in energy output and intake. Edholm (196I) comments on the same phenomenon in young men engaged in fairly strenuous work. Kennedy (1961) draws attention to the distinction between the regulation of appetite and longterm energy balance. Morrison (1959) has reviewed some of the evidence derived from experimental animals on the mechanisms which regulate appetite.

\section{Influence of the menstrual cycle}

In baboons (Papio ursinus) the calorie intake falls sharply during the first 6-I I days of the cycle to a minimum near the time of ovulation and then rises to a maximum in the late premenstruum. Injection of progesterone at a time when the calorie intake is low results in an increase in calorie intake. During the follicular phase of the cycle there is a rapid increase in body-weight, mainly due to accumulation of water in the sexual skin; during perineal deturgescence in the luteal phase body-weight falls again (Gilbert \& Gillman, 1956; Gillman \& Gilbert, 1956).

The results of studies on women have been much less complete and definite. Sweeney (1934) and Thorn, Nelson \& Thorn (1938) found that $30-50 \%$ of normal women gained I $\mathrm{kg}$ or more of body-weight during the premenstrual or menstrual phase of the cycle. Some of those who gained weight reported an increase of appetite or thirst. Thorn et al. (1938) also gave diets of constant energy value and water content to four women: in three of the women water excretion rose and body-weight fell when menstruation began. Thomas (1953) found that the curves of daily body-weight of fourteen women varied greatly one from another, but peaks of weight often occurred about the time of menstruation and at mid-cycle. On the other hand, Chesley \& Hellman (1957) concluded from a similar study, and from a study of previously published data, that the incidence of premenstrual peaks of weight could be due to chance alone. There seems to be no evidence that women experience greater daily weight changes than men, with the exception of women with clinically obvious premenstrual oedema. Yudkin (195I) reported that the average weekly calorie intakes of five student dietitians varied considerably from week to week, but no obvious relation was found between food consumption and menstruation. In a prolonged study of one 
woman Chappell (1955) found the calorie intake to be raised by physical exercise and by very cold weather; the effect of menstruation, if any, was masked by variation from other causes.

In the investigation of a single subject reported here no changes of body-weight, food intake, water intake or urinary output were found that could be attributed to menstruation. This does not imply that such changes were completely absent but rather that, if any cyclical variations were present, they were completely masked by variation from other causes. The picture may differ with the individual but the negative findings with this subject suggest that a conclusive answer could be obtained only in a study of many subjects for long periods of time.

Oestrogens are believed to cause retention of water (Dignam, Voskian \& Assali, 1956; Preedy \& Aitken, 1956) so it is a little surprising that no evidence of such retention was obtained when oestriol excretion rose in mid-cycle, especially when a sharp peak of oestriol excretion occurred between menstruations in period (A).

During the second menstrual cycle of period (A) pregnanediol excretion remained uniformly low, suggesting that this cycle was anovulatory. This is probably not evidence of an abnormality. According to de Allende (1956), it is exceptional for a woman to have ovulatory cycles only; he suggests that at least three or four anovulatory cycles during the year are usual. In about $50 \%$ of the cycles, judged by de Allende to have been anovulatory on the basis of vaginal smears, the temperature charts showed the usual rise in mid-cycle.

\section{SUMMARY}

I. The daily intake of food and of water, the volume of urine excreted daily and the basal body-weight of a non-pregnant woman were measured for 80 days. During part of this time records of activity were kept. During a subsequent period of 35 days the food intake was kept constant and daily activity was regulated as far as possible. Water intake was not regulated in either period.

2. During the first period the calorie intake varied widely and showed a marked variation with the day of the week. In both periods body-weight also fluctuated; fluctuations in weight were smaller in the second than in the first period.

3. Day-to-day changes in body-weight appeared to be related mainly to changes in water balance. Over longer periods the general trend of weight followed that of the calorie intake.

4. Calorie intake was not related to activity on the same day. A small but significant relationship was found between activity on one day and calorie intake on the next.

5. Changes in body-weight, food intake and water balance were not related to the menstrual cycle or to excretion of pregnanediol and oestriol in the urine.

I wish to thank Mr W. Z. Billewicz for carrying out the statistical analysis of the results and for his help in presenting them; Dr A. Klopper for the estimation of urinary excretion of oestriol and pregnanediol; and members of the staff of the Meteorological Office at Dyce, Aberdeenshire, for providing data on atmospheric temperature. 


\section{REFERENCES}

Brebner, D. F., Kerslake, D. McK. \& Waddell, J. L. (1956). F. Physiol. 132, 225.

Brown, J. B. (1955). Biochem. F. 6o, 185 .

Brown, J. B., Bulbrook, R. D. \& Greenwood, F. C. (1957-8). F. Endocrin. r6, 49.

Chappell, G. M. (1955). Brit. F. Nutr. 9, 323.

Chesley, L. C. \& Hellman, L. M. (I957). Amer. F. Obstet. Gynec. 74, 582.

Cumming, Mary C. \& Morrison, S. D. (1960). F. Physiol. 154, 2 19.

de Allende, I. L. C. (1956). Amer. F. Anat. 98, 293.

Dignam, W. S., Voskian, J. \& Assali, N. S. (1956). F. clin. Endocrin. 16, то32.

Durnin, J. V. G. A. (196r). Proc. Nutr. Soc. 20, 52.

Edholm, O. G. (1961). Proc. Nutr. Soc. 20, 7 I.

Elkinton, J. R. \& Danowski, T. S. (1955). The Body Fluids, Chapter I, p. 26. Baltimore: The Williams and Wilkins Co.

FAO: Second Committee on Calorie Requirements (1957). F.A.O. nutr. Stud. no. 15 .

Gilbert, C. \& Gillman, J. (1956). S. Afr. F. med. Sci. 21, 75.

Gillman, J. \& Gilbert, C. (1956). Amer. F. Anat. 98, 23 I.

Heller, H. (1932). Z. ges. exp. Med. 83, I28. Quoted in Nutr. Abstr. Rev. (1933-4), 3, 47.

Kennedy, G. C. (196r). Proc. Nutr. Soc. 20, 58.

Klopper, A., Michie, E. A. \& Brown, J. B. (1955). F. Endocrin. 12, 209.

Manery, J. F. (1954). Physiol. Rev. 34, 334.

Medical Research Council: Accessory Food Factors Committee (1945). M.R.C. (War) Memor. no. 14.

Morrison, S. D. (1959). Proc. Nutr. Soc. 18, 141.

McCance, R. A. \& Widdowson, E. M. (1946). Spec. Rep. Ser. med. Res. Coun., Lond. no. 235, 2 nd ed.

Newburgh, L. H. (1950). In Clinical Nutrition, p. 689. [N. Jolliffe, B. F. Tisdall and P. R. Cannon, editors.] New York: Paul B. Hoeber Inc.

Osborne, W. A. (1910). F. Physiol. 41, 345.

Passmore, R., Meiklejohn, A. P., Dewar, A. D. \& Thow, R. K. (1955). Brit. F. Nutr. 9, 27.

Preedy, J. R. K. \& Aitken, E. H. (1956). F. clin. Invest. 35, 423.

Sweeney, J. S. (1934). F. Amer. med. Ass. ro3, 234.

Thomas, C. B. (1953). Ann. intern. Med. 39, 289.

Thorn, G. W., Nelson, K. R. \& Thorn, D. W. (1938). Endocrinology, 22, 155.

Wiley, F. H. \& Newburgh, L. H. (193 I). F. clin. Invest. 10, 689.

Yudkin, J. (195I). Brit. F. Nutr. 5, I77. 